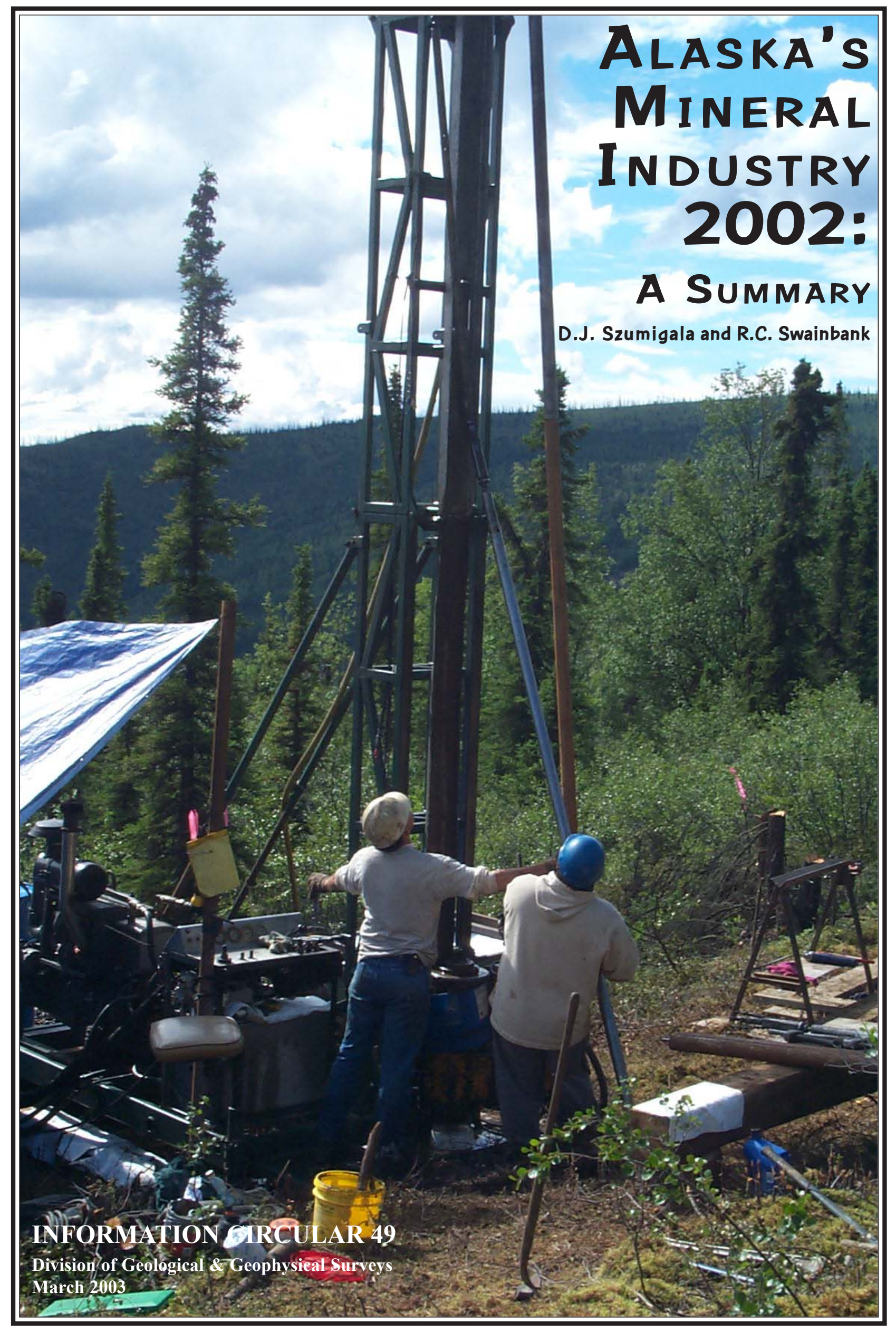




\title{
Alaska's Mineral Industry 2002: A Summary
}

\author{
by \\ D.J. Szumigala ${ }^{1}$ and R.C. Swainbank ${ }^{2}$
}

\section{INTRODUCTION}

This summary of Alaska's mineral industry activity for 2002 is made possible by information provided through press releases, annual reports, phone interviews and replies to questionnaires mailed by the Alaska Division of Geological \& Geophysical Surveys (DGGS). The final report will be available later in the year after further compilation of information, particularly for placer mining and industrial minerals. This report is part of a cooperative venture between DGGS and the Division of Mining, Land, \& Water (DMLW) in the Department of Natural Resources (DNR) and the Division of Community \& Business Development (DCBD) in the Department of Community \& Economic Development (DCED). The estimates used in this summary are generally conservative due to incomplete data. This summary and data contained within it will be superceded by DGGS Special Report 57 to be published later in 2003 .

Table 1 shows the estimated value of the mineral industry in Alaska per year between 1981 and 2002, as divided between exploration and development investments, and the gross value of the mineral products. These preliminary combined values totaled $\$ 1,026.7$ million in 2002, compared with $\$ 1,022.3$ million in 2001. The low level of development investment ( $\$ 33.5$ million) in 2002 compared with the $\$ 81.2$ million reported in 2001 was more than offset by the increased value of mineral products ( $\$ 968.2$ million) in 2002 compared with $\$ 917.3$ million in 2001. Had the price of zinc not declined 12.5 percent in 2002 (compared with 2001 levels), the gross value of the mineral products would have been almost $\$ 72$ million greater. The exploration investment of $\$ 25.0$ million in 2002 was slightly larger than the \$23.8 million in 2001.

Exploration during 2002 occurred across most regions of the state, with almost half of the exploration funds spent in southwestern Alaska. Eastern Alaska was the next most active region, but expenditures dropped almost to half of 2001 levels. More than $\$ 17$ million was spent exploring on gold and associated precious metal projects across the
Table 1. Total value of the mineral industry in Alaska by year (in millions of dollars)

Exploration Development Production Total (expenditure) (expenditure) (value) (calculated)

\begin{tabular}{lrrrr}
1981 & 76.3 & 24.7 & 188.6 & 289.6 \\
1982 & 45.6 & 41.6 & 196.4 & 283.7 \\
1983 & 34.1 & 27.9 & 212.4 & 274.4 \\
1984 & 22.3 & 53.4 & 199.4 & 275.1 \\
1985 & 9.2 & 34.1 & 226.6 & 269.9 \\
1986 & 8.9 & 24.3 & 198.5 & 231.7 \\
1987 & 15.7 & 100.3 & 202.4 & 318.4 \\
1988 & 45.5 & 275.0 & 232.2 & 552.6 \\
1989 & 47.8 & 134.3 & 277.0 & 459.0 \\
1990 & 63.3 & 14.3 & 533.0 & 610.6 \\
1991 & 39.9 & 25.6 & 546.5 & 612.0 \\
1992 & 30.2 & 29.6 & 560.8 & 620.6 \\
1993 & 30.3 & 27.7 & 448.7 & 506.7 \\
1994 & 31.1 & 45.0 & 507.5 & 583.6 \\
1995 & 34.3 & 148.6 & 537.2 & 720.1 \\
1996 & 44.7 & 394.0 & 590.4 & $1,029.2$ \\
1997 & 57.8 & 168.4 & 936.2 & $1,162.4$ \\
1998 & 57.3 & 55.4 & 921.2 & $1,033.9$ \\
1999 & 52.3 & 33.8 & $1,032.9$ & $1,119.0$ \\
2000 & 34.9 & 141.7 & $1,106.4$ & $1,283.0$ \\
2001 & 23.8 & 81.2 & 917.3 & $1,022.3$ \\
2002 & 25.0 & 33.5 & 968.2 & $1,026.7$ \\
& & & & \\
TOTAL & $\mathbf{\$ 8 3 0 . 3}$ & $\mathbf{\$ 1 , 9 1 4 . 4}$ & $\mathbf{\$ 1 1 , 5 3 9 . 8}$ & $\mathbf{\$ 1 4 , 2 8 4 . 5}$ \\
\hline
\end{tabular}

SouRCE: Alaska's mineral industry reports published annually by DGGS.

state. The largest exploration project in Alaska was NovaGold Resources' Donlin Creek gold property in southwestern Alaska. Other large projects were Northern Dynasty's Pebble project in southwestern Alaska, Kinross Gold's Fairbanks mining district exploration program, and Kennecott's exploration program at Greens Creek Mine.

The decline in development investment mainly reflects completion of ongoing projects at Red Dog Mine in northern Alaska, but small projects were reported at the Fort Knox/True North complex, Usibelli Coal Mine, and Pogo in the interior, and at Kensington and Greens Creek mines in southeastern Alaska.

\footnotetext{
${ }^{1}$ Alaska Division of Geological \& Geophysical Surveys, 794 University Ave., Suite 200, Fairbanks, Alaska 99709-3645

${ }^{2}$ Alaska Division of Community and Business Development, Unit \#7, 3677 College Rd., Fairbanks, Alaska 99709
} 
Production at Greens Creek Mine reached record levels, and was robust at Fort Knox and Red Dog Mine. Placer gold production levels were comparable to those of the previous year, and are expected to increase in 2003 corresponding to the rising price of gold.

\section{EMPLOYMENT}

Table 2 lists estimated employment in the Alaska mineral industry for the past seven years. The total minerals industry employment in 2002 is estimated to be 2,695 full-time-equivalent jobs, a drop of about 140 jobs from the 2,835 jobs reported in 2001. Most of the decline was in the development sector, counteracted to some extent by an increase in the industrial minerals sector and lode gold mine employment.

\section{EXPLORATION}

Estimated exploration expenditures in Alaska during 2002 are about $\$ 25$ million, a $\$ 1.2$ million increase compared to expenditures of $\$ 23.8$ million in 2001. The value of mineral exploration is still low compared to spending levels in the late 1980s through late 1990s. Several large projects, notably NovaGold Resources Inc.'s Donlin Creek gold project, Northern Dynasty's Pebble copper-gold project, Kennecott's Greens Creek mine exploration and Kinross Gold Corp.'s Fairbanks mining district gold projects, accounted for most of the exploration expenditures and drill footage. Almost half of the 2002 Alaska exploration expenditures were spent in southwestern Alaska The eastern interior region saw a sharp reduction in activity, while the Seward Peninsula experienced a rebirth in activity. Gold remained the major exploration commodity, but base metal and platinum-group-element exploration increased from recent levels. As in years past, most exploration funds, over 70 percent, were derived from Canadian sources. Table 3 lists exploration expenditures by commodity. Figure 1 shows the location of the most significant exploration projects in Alaska during 2002.

\section{Northern Region}

Kennecott Exploration Co. planned to conduct mineral exploration, including core drilling, in the Wulik River area near the Lik camp. Previous work in this area during 2001 included collecting more than 500 geochemical samples, collecting gravity data from more than 1,500 sites, and mapping the geology of selected sites.

\section{Western Region}

The Seward Peninsula was the center of activity for the western region of Alaska. The major projects in the area are described below. Other exploration projects included work by Greatland Exploration Inc. on the Omalik property. Altar Resources and subsidiary Royal Pretoria Gold Ltd. continued exploration on gold prospects not joint ventured with other companies.

NovaGold Resources Inc. and TNR Resources Ltd. finalized a joint-venture agreement to advance the million-ounce gold resource at the Rock Creek property near Nome toward production within the next 3 years. Under terms of the agreement TNR Resources would earn a 49.9 percent interest in the project by spending $\$ 10$ million on exploration and development to bring the project to production by June 2005. As part of the agreement, TNR Resources will issue 500,000 shares to NovaGold. NovaGold previously released a total

Table 2. Estimated Alaska mine employment, 1996-2002 ${ }^{a}$

\begin{tabular}{|c|c|c|c|c|c|c|c|}
\hline & 1996 & 1997 & 1998 & 1999 & 2000 & 2001 & 2002 \\
\hline \multicolumn{8}{|l|}{ Gold/silver mining } \\
\hline Placer & 825 & 780 & 710 & 591 & 470 & 176 & 160 \\
\hline Lode & 138 & 415 & 345 & 296 & 274 & 337 & 413 \\
\hline Polymetallic & 68 & 230 & 275 & 275 & 275 & 275 & 262 \\
\hline Base metals & 407 & 478 & 466 & 549 & 556 & 559 & 560 \\
\hline Recreational & 260 & 270 & 255 & 240 & 250 & 210 & 190 \\
\hline Sand \& gravel & 598 & 700 & 658 & 590 & 603 & 556 & 660 \\
\hline Rock & 149 & 123 & 121 & 128 & 150 & 137 & 107 \\
\hline Coal & 115 & 118 & 128 & 121 & 121 & 121 & 95 \\
\hline Peat & 38 & 42 & 40 & 38 & 36 & 32 & 21 \\
\hline $\begin{array}{l}\text { Tin, jade, soapstone, } \\
\text { ceramics, platinum }\end{array}$ & 20 & 20 & 20 & 20 & 20 & 20 & 20 \\
\hline Mineral development & 862 & 409 & 177 & 135 & 345 & 333 & 135 \\
\hline Mineral exploration & 257 & 277 & 282 & 183 & 83 & 79 & 72 \\
\hline TOTAL & 3,737 & 3,862 & 3,477 & 3,166 & 3,183 & 2,835 & 2,695 \\
\hline
\end{tabular}

${ }^{\mathrm{a} C a l c u l a t e d ~ o n ~ a ~ 260-d a y ~ w o r k ~ y e a r . ~}$ 
Table 3. Reported exploration expenditures in Alaska by commodity, 1982-2002

\begin{tabular}{|c|c|c|c|c|c|c|c|}
\hline & $\begin{array}{l}\text { Base } \\
\text { metals }\end{array}$ & Polymetallic $^{\mathbf{a}}$ & $\begin{array}{c}\text { Precious } \\
\text { metals }\end{array}$ & $\begin{array}{l}\text { Industrial } \\
\text { minerals }\end{array}$ & $\begin{array}{c}\text { Coal } \\
\text { and peat }\end{array}$ & Other $^{b}$ & Total \\
\hline 1982 & $\$ 31,757,900$ & N/A & $\$ 10,944,100$ & -- & $\$ 2,900,000$ & $\$ \quad 15,300$ & $\$ 45,617,300$ \\
\hline 1983 & $9,758,760$ & N/A & $20,897,555$ & $2,068,300$ & $1,338,454$ & 70,000 & $34,133,069$ \\
\hline 1984 & $4,720,596$ & N/A & $14,948,554$ & 270,000 & $2,065,000$ & 279,500 & $22,283,650$ \\
\hline 1985 & $2,397,600$ & N/A & $6,482,400$ & - & 270,000 & - & $9,150,000$ \\
\hline 1986 & $1,847,660$ & N/A & $6,107,084$ & 170,000 & 790,000 & - & $8,914,744$ \\
\hline 1987 & $2,523,350$ & N/A & $11,743,711$ & 286,000 & $1,150,000$ & 31,000 & $15,734,061$ \\
\hline 1988 & $1,208,000$ & N/A & $41,370,600$ & 160,200 & $2,730,000$ & - - & $45,468,800$ \\
\hline 1989 & $3,503,000$ & N/A & $43,205,300$ & 125,000 & 924,296 & 5,000 & $47,762,596$ \\
\hline 1990 & $5,282,200$ & N/A & $57,185,394$ & 370,000 & 321,000 & 97,000 & $63,255,594$ \\
\hline 1991 & $4,789,500$ & N/A & $34,422,039$ & 92,000 & 603,000 & 2,000 & $39,908,539$ \\
\hline 1992 & $1,116,000$ & $3,560,000$ & $25,083,000$ & 25,000 & 425,000 & -- & $30,209,000$ \\
\hline 1993 & 910,000 & $5,676,743$ & $23,382,246$ & 163,500 & -- & 125,000 & $30,257,489$ \\
\hline 1994 & 600,000 & $8,099,054$ & $18,815,560$ & 225,000 & $2,554,000$ & 810,000 & $31,103,614$ \\
\hline 1995 & $2,770,000$ & $10,550,000$ & $20,883,100$ & 100,000 & -- & 3,000 & $34,306,100$ \\
\hline 1996 & $1,100,000$ & $11,983,364$ & $31,238,600$ & 400,000 & -- & -- & $44,721,964$ \\
\hline 1997 & $1,700,000$ & $22,347,000$ & $32,960,500$ & 80,000 & 720,000 & - & $\mathbf{5 7 , 8 0 7 , 5 0 0}$ \\
\hline 1998 & $1,000,000$ & $13,727,000$ & $42,441,000$ & 12,000 & 87,000 & - & $57,267,000$ \\
\hline 1999 & $3,869,000$ & $3,168,000$ & $44,891,000$ & 1,000 & -- & 410,000 & $52,339,000$ \\
\hline 2000 & $8,545,000$ & $3,933,000$ & $21,579,000$ & 58,500 & - - & 736,100 & $34,851,600$ \\
\hline 2001 & $4,810,000$ & $1,977,000$ & $15,820,000^{\mathrm{c}}$ & 50,000 & 10,000 & $1,106,000$ & $23,773,000$ \\
\hline 2002 & $1,700,000$ & $5,081,000$ & $16,044,000$ & 185,000 & -- & $2,040,000$ & $25,050,000$ \\
\hline TOTAL & $\$ 95,908,566$ & $\$ 90,102,161$ & $\$ 540,444,743$ & $\$ 4,841,500$ & $\$ 16,887,750$ & $\$ 5,729,900$ & $\$ 753,914,620$ \\
\hline
\end{tabular}

Figure 1. Projects shown on this map represent $\$ 22$ million of the $\$ 25$ million spent on exploration in Alaska during 2002.

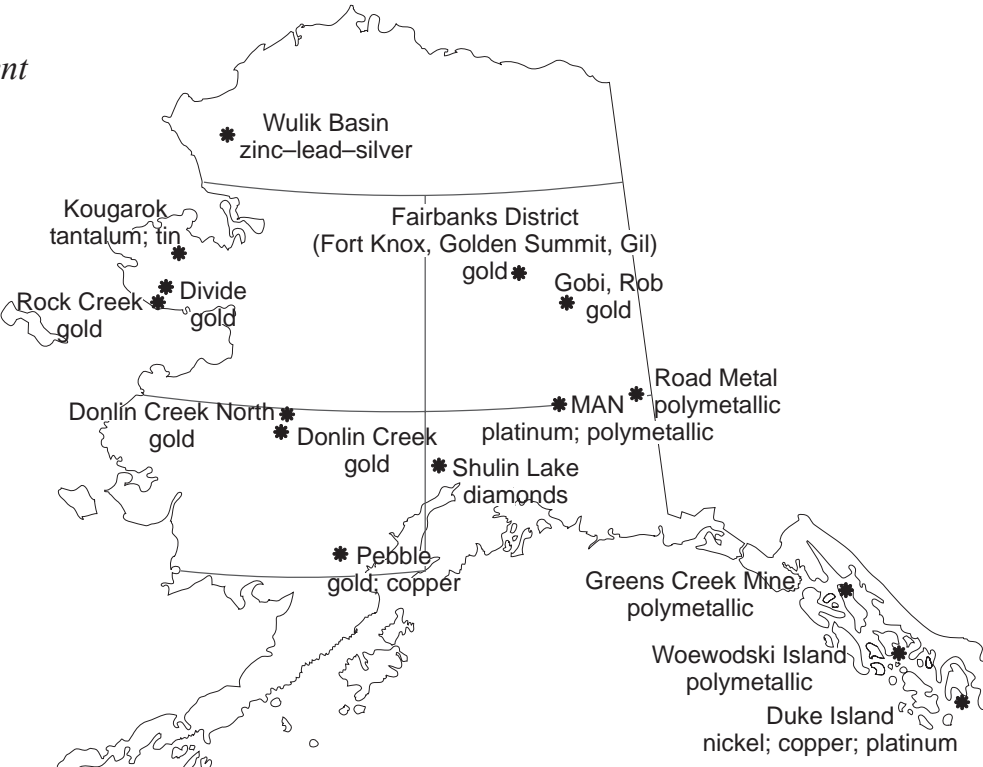


Measured and Indicated Resource of 555,000 ounces grading 0.08 ounces per ton gold with an additional Inferred Resource of 303,000 ounces of gold grading 0.081 ounces per ton using a 0.029 ounces per ton cut-off grade, based on work completed by NovaGold, Kennecott, Newmont, and Placer Dome at Rock Creek. The adjacent Saddle deposit contains an additional Inferred Resource of 260,000 ounces of gold grading 0.076 ounces per ton gold using a 0.029 ounces per ton cut-off grade.

The 2002 drill and trench program at Rock Creek was designed to expand the extent of the known gold resource and to complete in-fill core drilling along the higher-grade Albion Zone. The drill program consisted of $16 \mathrm{HQ}$ core holes totaling 3,878 feet that successfully intersected targeted shallow high-grade Albion zone and surrounding vein mineralization. Gold grades within these drill holes confirm previous results, and closer spaced drilling should upgrade some resources to the higher measured and indicated categories. Drilling also extended the overall mineralized zone to longer than 1 mile in strike length. The system remains open along strike and down dip and there remains excellent potential to continue to expand the higher-grade Albion Zone, as well as to discover new zones with further drilling. Drill highlights from 2002 include: drill hole 101 with 111.6 feet grading 0.047 ounces per ton gold, including 6.6 feet at 0.5 ounces per ton; hole 102 with 200 feet grading 0.044 ounces per ton gold, including 13 feet at 0.15 ounces per ton gold, hole 105 with 288.7 feet grading 0.037 ounces per ton gold, including 32.8 feet at 0.16 ounces per ton gold; drill hole 115 where the entire 344.5 foot hole averaged 0.025 ounces per ton gold and included 26.25 feet grading 0.103 ounces per ton gold with a separate interval of 39.4 feet grading 0.118 ounces per ton gold; and drill hole 116 with 380.6 feet grading 0.05 ounces per ton gold from top to bottom, including 52.5 feet grading 0.09 ounces per ton gold with a separate interval of 91.9 feet grading 0.134 ounces per ton gold.

Initial trenching at Rock Creek on a broad gold-in-soil anomaly approximately 1,000 feet south of the modeled pit exposed a zone of stockwork veining and disseminated sulfide mineralization. High-grade gold mineralization, up to 39 feet of 0.15 ounces per ton gold, intercepted in trench RKT-104 is more than 400 feet southwest of the currently drilled resource. Also sampling at the end of Trench RKT111 , more than 150 feet northeast of the modeled pit limit, showed highly anomalous gold and trace-element geochemistry consistent with peripheral Albion zone mineralization. Several other nearby soil anomalies also hold significant potential for similar styles of mineralization and will be targeted for work in 2003.

Navigator Exploration Corp. and Chapleau Resources Ltd. planned a minimum $\$ 600,000$ drilling program on the Kougarok tantalum-tin prospect in the north-central
Seward Peninsula, approximately 67 miles north of Nome, Alaska. The Kougarok property appears to be underlain by a large, multiphase intrusion that incorporates a number of satellitic mineralized cupolas formed by tantalum-enriched albite-zinnwaldite granites. Numerous significant drill intercepts of tin and tantalum mineralization in previous work (early 1980s) were encountered from a cupola known as the "main plug." Surface exploration undertaken by Navigator and Chapleau during 2001 identified new showings at the Hill Top and Real Top prospects elsewhere on the property that were incorporated into the 2002 drilling program.

Five geographically distinct target areas were selected for the 2002 Kougarok work program to test geologic models, evaluate newly discovered mineral showings and confirm tantalum values reported by Anaconda. In excess of 500 rock samples were collected during a property-wide prospecting program that ran concurrently with the 2002 drilling. Analytical results pertaining to these samples were not released. Approximately 8,000 feet of drilling was completed in seven vertical holes and a total of 259 samples were split for analysis. The holes were collared over an area of about 2 square miles with distances between holes ranging from 700 feet to more than a mile. Each hole encountered anomalous tantalum values at the hanging wall contact (that is, upper surface) of the targeted zinnwaldite granite. Only hole 2002-04, located on the previously untested eastern margin of the main plug, returned potentially economic values of tantalum. Zinnwaldite granite related to the main plug was intercepted between 429 and 1,003 feet. The best intercept within this interval was 347.5 feet grading 0.017 percent $\mathrm{Ta}\left(0.021\right.$ percent $\left.\mathrm{Ta}_{2} \mathrm{O}_{5}\right)$ from 443 to 791 feet, including 184 feet grading 0.021 percent $\mathrm{Ta}$ ( 0.026 percent $\mathrm{Ta}_{2} \mathrm{O}_{5}$ ) from 585.7 to 769 feet and 103 feet grading 0.023 percent $\mathrm{Ta}\left(0.029\right.$ percent $\left.\mathrm{Ta}_{2} \mathrm{O}_{5}\right)$ from 585.7 to 689 feet. The program confirmed the presence of a large, well-preserved, tantalum-bearing granitic system. Given current tantalum prices, however, the economic potential of the deposit appears limited at this time.

Quaterra Resources Inc. drill tested three road-accessible projects on the Seward Peninsula with drill targets established by coincident gravity and geochemical anomalies. The four diamond drill holes on the properties failed to intercept mineralization. As a result, Quaterra relinquished rights to the Think Zinc, Sinuk River, and Rocky Mountain Creek projects. Quaterra retained the 100-percent-owned Big Bar prospect.

Rio Fortuna Exploration Corp. acquired the road-accessible Divide Project 28 miles north of Nome. Rio Fortuna may earn a 100 percent interest in the property by making cash payments totaling $\$ 1$ million over a 5-year period and issuing 1 million shares of Rio Fortuna common stock. The property will be subject to a sliding scale NSR royalty ranging from 2 percent at a gold price of 
$\$ 300$ or less to 5 percent at a gold price of $\$ 500$ or more. A large 0.029 ounces per ton gold-in-soil anomaly lies within the northeastern sector of a larger 8,000 feet by 4,500 feet gold-in-soil anomaly that averages greater than 0.003 ounces per ton. Rio Fortuna drilled 16 holes, totaling 4,452 feet, from eight drill pads to test flat-lying quartz-albite-arsenopyrite veins and silicified zones within a graphitic schist horizon over a strike length of 1,500 feet by 1,000 feet. Silicification was traced through nine out of eleven drill holes. Hole 02RF-5 intersected 39 feet of 0.048 ounces per ton gold. Other gold values in drill samples ranged from 0.007 ounces per ton up to 0.181 ounces per ton in 14 of 18 drill holes. Sample widths ranged from a minimum 6.5 feet to 52 feet.

Rio Fortuna also completed a first phase reconnaissance program on the 24-square-mile Full Auto project, which also is road accessible, 12 miles northwest of Nome. A total of 560 stream sediment, soil, and rock samples have been collected from this area, which is unexplored for lode resources but which has seen placer development on four creeks during the early 1900s. Gold placer concentrates from Hungry Creek contained native bismuth nuggets while it has been reported that gold-bearing native bismuth and scheelite in placer gold concentrates have been found at Nugget Gulch and Oregon Creek.

\section{Eastern Interior Region}

Kinross Gold Corp. continued exploration in the Fairbanks mining district with extensive drilling around the True North gold deposit. A mix of diamond and reverse-circulation drilling at True North continued throughout the year to focus on the conversion of resources to reserves and to outline the limits of mineralization. An aggressive drill-based exploration program was conducted at the Fort Knox pit and surrounding area. Kinross also planned to conduct a reverse-circulation drill program on the leased Steamboat Creek property.

No exploration work was conducted on the Pogo property in 2002. However, Teck Cominco's Pogo gold project in Interior Alaska received its Preliminary Environmental Impact Statement (EIS) from the U.S. Environmental Protection Agency (EPA) and public review is anticipated in early 2003. The EPA draft EIS should be followed by a 60-day public comment period. The State Department of Natural Resources will release its recommendations as an attachment to the draft EIS. Teck completed permitting, condemnation and infill drilling, and feasibility studies during 2002. Teck drilled over 30,000 of core as part of an infill- and condemnation-drilling program. If permitting proceeds on schedule, construction may begin by late 2003 .

AngloGold (USA) Exploration Inc. conducted a threehole, 3,569-foot diamond-drilling program on Continental Ridge Resources Inc.'s 351-claim Gobi-Portal property, located 3 miles west of the Pogo deposit owned by Teck
Cominco and Sumitomo Metals. AngloGold can earn a 60 percent interest in the Gobi-Portal property from Continental Ridge by making certain cash payments and spending $\$ 750,000$ on exploration over a 5-year period. Drilling at the Hook target intersected a 330-foot-wide zone of gold mineralization hosted by granodiorite intrusive rocks near their contact with surrounding gneissic metamorphic rocks. Gold occurs in quartz veinlets with occasional calcite, tourmaline, pyrite, and arsenopyrite. Multiple sericite-altered, quartz-veined zones were intersected in hole AGGP-1. The best assay results returned 0.031 ounces per ton gold over 10 feet, including 0.153 ounces per ton gold over 1.6 feet. Additional drilling is planned for 2003.

AngloGold also signed two option agreements with Rimfire Minerals Corp. to earn up to a 70 percent interest in the Eagle and ER-Ogo-Fire properties. Initially, AngloGold may earn a 50 percent interest in the properties by making exploration expenditures totaling $\$ 400,000$ per property and paying Rimfire $\$ 100,000$ per property in staged cash payments over 4 years. AngloGold may increase its interest in the properties to 70 percent by incurring an additional $\$ 500,000$ in exploration expenditures per property. AngloGold conducted sampling and reconnaissance exploration, including soil and rock sampling programs on the properties. AngloGold North America Inc. also signed an agreement with Zeus Exploration Inc. to earn a 65 percent vested interest in Zeus's West Pogo properties.

North Star Exploration Inc. continued a large exploration program, including drilling, at the Road Metal property near Northway. Tri-Valley Corp. continued gold exploration in the Richardson district.

Freegold Ventures Ltd. (Freegold), formerly International Freegold Mineral Development Inc., acquired the Rob gold project in the Goodpaster Mining District, Alaska, a high-grade gold prospect about 20 miles southeast of the Pogo deposit. Freegold has an option to acquire a 100 percent interest in the property subject to payments totaling $\$ 29,000$ in cash over 7 years, plus payment of 500,000 shares prior to July 2003 and an additional 500,000 shares once Freegold has spent $\$ 1$ million on exploration. The property is also subject to a 1 percent net smelter return royalty. The Rob property is cut by a series of early $\mathrm{N} 50^{\circ} \mathrm{E}$-trending high-angle structures (Double Bear, Gray Lead, and Black Mountain faults) that are cut by younger east-west-trending high-angle structures (such as the Wolverine fault). Most previously discovered precious metal veins on the property trend parallel to $\mathrm{N} 50^{\circ} \mathrm{E}$-trending structures in areas where Cretaceous granitic bodies are present. Limited sampling by Freegold in 2002 returned good results. Gold mineralization at both the Gray Lead and Hilltop prospects is controlled by the northeast-striking Gray Lead fault, which cuts sericite- 
altered Cretaceous granitic rocks and Paleozoic biotite gneiss. Mineralization is hosted in quartz veins and stockworks containing gold, arsenopyrite, bismuthinite, and an unknown tellurium-bearing mineral. Gold (up to 2.1 ounces per ton) is associated with highly anomalous arsenic (up to 10,000 parts per million), bismuth (up to 1,610 parts per million), and tellurium (up to 180 parts per million) and locally with elevated antimony (up to 1,000 parts per million) and tungsten (up to 495 parts per million). Mineralization on the Michigan, Upper-Lower Trench and O'Reely prospects is hosted in sericite-altered Cretaceous granitic rocks and Paleozoic biotite gneiss. Mineralization at these prospects is hosted in quartz veins, stockworks and quartz breccias containing visible gold (up to 20.4 ounces per ton) with highly anomalous arsenic (up to 1 percent), antimony (up to 0.1 percent) and lesser bismuth (up to 39 parts per million). Gold mineralization on these prospects does not appear to be associated with elevated bismuth, tellurium, or tungsten, suggesting a genetically different style of mineralization from that seen on the Gray Lead prospect. Coarse visible gold was identified at surface on the Michigan lode and returned values up to 20 ounces gold per ton. This part of the Rob prospect has never been drilled. A single grab sample from unsplit diamond drill core from the Lower Trench prospect returned 0.12 ounces per ton gold from strongly quartz-sericite-altered granitic rock. The extent of this mineralization is unknown.

Freegold also conducted an exploration program on the Golden Summit property on Cleary Summit in the Fairbanks mining district. Freegold conducted a resistivity survey over the Currey Zone and then dug trenches based on interpretation of the geophysics and previous geochemical sampling. Grab samples of quartz vein material in the trenches returned values up to 6.167 ounces per ton gold while channel sample values ranged up to 10 feet grading 0.125 ounces per ton and 29 feet grading 0.034 ounces per ton. One 5 -foot channel sample assayed 0.337 ounces per ton gold. Approximately 100 feet of new backhoe trenching was conducted in a second phase and approximately 30 new channel and grab samples were collected. A trench extension exposed additional mineralization including an 18-inch-thick polyphase quartz vein that contained abundant coarse, visible gold with assays grading up to 12.5 ounces per ton gold. Grab sample geochemical results range from 0.127 to 12.5 ounces per ton gold, with five grab samples containing in excess of 1 ounce per ton gold.

Freegold's Currey Zone trenching program was designed to confirm hole CHD00-1 (64 feet grading 0.138 ounces per ton gold) and to test for continuity of mineralization along strike. The trenching program confirmed that hole CHD00-1 intersected a major system of veins and shear zones carrying significant gold values, the multi vein/ shear zone system extends laterally with significantly mineralized widths similar to CHD00-1, and the mineralization "packet" is exposed at surface and is open along strike. Gold mineralization is associated with quartz, quartz-carbonate or quartz sulfide bearing veins and with shear zones where quartz volume is relatively low. Most of the mineralized structures mapped in the trenches trend $\mathrm{N} 60^{\circ}-80^{\circ} \mathrm{W}$ and dip steeply south. These structures range from quartz veins with no apparent wall rock alteration or shearing to iron oxide-stained, schist-hosted breccia and shear zones up to 100 feet in width containing 1 to 20 percent crushed quartz in pods and veinlets. Bedrock hosting the mineralization consists of highly oxidized quartzite, quartz mica schist, chlorite schist and local actinolite schist cut by quartz, quartz-carbonate and quartz-carbonate-sulfide veins ranging from 1 inch to 25 inches thick. High-grade gold mineralization is associated with elevated arsenic and with sporadic anomalous silver, lead, bismuth, antimony, and tungsten. Based on these results, Freegold intends to carry out a step out drilling program, possibly 4,000 feet of diamond core drilling in 8 to 10 holes, from the site of drillhole CHD00-1 during the 2003 winter.

In addition to the above exploration programs, Freegold also entered into an agreement with Anglo Alaska Gold Corp. whereby Freegold may earn a 100 percent interest in the Yeager Property adjacent the Golden Summit Property. The acquisition of the Yeager Property increases the Golden Summit land block to approximately 18,000 acres.

Teryl Resources Corp., with Kinross Gold Corp., announced encouraging drilling and surface exploration results at the Gil joint venture property in the Fairbanks mining district. Teryl Resources owns a 20 percent working interest and Kinross Gold owns an 80 percent working interest in the Gil joint venture property. Infill drilling on the Main Gil deposit area at hole GVC02-264 intercepted 220 feet of gold mineralization including 80 feet of 0.06 ounces per ton gold from 20- to 100-foot depth. Infill drilling at the North Gil deposit area succeeded with thick intercepts of significant gold grades in the southwestern portion of the North Gil resource area where previous drilling has been limited. Drillhole GVC02-262 intercepted 15 feet of 0.095 ounces per ton gold at depths from 65 to 80 feet and 10 feet of 0.087 ounces per ton gold from 200 to 210 feet, and drillhole GVC02-263 with four mineralized zones from 5 to 55 feet thick from 75 - to 975 -foot depths ranging from 0.040 to 0.105 ounces per ton gold. At the Slippery Creek prospect, drillhole GVC02-266 intersected 20 feet of 0.078 ounces per ton gold from 20 - to 40 -foot depth. A new zone of mineralization was intercepted in the Sourdough Ridge prospect in drillhole GVC02-267 and consists of 15 feet (from 95- to 110-foot depth) of 0.49 ounces per ton gold, including a 5 foot section of 1.34 ounces of gold per ton with anomalous arsenic and bismuth. Mineralization is hosted at the contact 
between overlying but barren calc-silicate altered metamorphic rocks in thrust-contact with underlying sericite-altered muscovite schist. The high-grade ore zone is hypothesized to be located where an east-west-trending high-angle structure intersects the favorable thrust horizon. Drilling completed this year and in previous years suggests mineralization continues to the northeast, according to consultant Avalon Development. Kinross Gold and Teryl plan additional work in 2003. Teryl Resources Corp. also planned to conduct an exploration and drilling program in early January 2003 on its 100-percent-owned Westridge property and its 50 percent option from Linux Wizardry Systems, Inc. on the Fish Creek property, both in the Fairbanks district.

Lockray Mining LLC planned to drill a reverse-circulation drill hole on the Bear Creek Ridge road in the Cleary Summit area of the Fairbanks mining district. No results have been announced.

The Alaska Division of Geological \& Geophysical Surveys (DGGS) conducted a regional geologic mapping project in the Salcha River-Pogo (SRP) geophysical tract within the Big Delta Quadrangle. Geologic mapping and geochemical sampling were conducted in a 60-day program stretching from the Salcha River near Caribou Creek to the Goodpaster River drainage near the Pogo gold property.

\section{Southcentral Region}

Nevada Star Resource Corp. continued fieldwork during 2002 at its MAN nickel-copper-platinum-groupelement (PGE) project near Tangle Lakes and the Denali Highway. Work included approximately 800 feet of core drilling on the Canwell Glacier property. The newly discovered Canwell Ridge occurrence consists of semi-massive to massive sulfide mineralization, from 0.5 feet to 6 feet thick, discontinuously exposed along a strike length of approximately 750 feet. The mineralization occurs within a peridotitic border phase of an ultramafic intrusion. Best results from float, grab, and chip samples ranged from 0.11 to 13.68 percent nickel, 0.12 to 4.51 percent copper, 0.001 to 0.147 ounces per ton gold, 0.001 to 0.590 ounces per ton platinum, and 0.008 to 0.500 ounces per ton palladium. Platinum values are greater than palladium values in most of the higher-grade samples.

An intensive program of mapping, prospecting, and geochemical sampling also focused on the northern or Eureka Block of Nevada Star's 117-square-mile property. Several new nickel-PGE showings were discovered. Exploration was also carried out on the Gezzi copper-gold prospect, an intrusion-hosted deposit with bulk tonnage potential, and the Broxson gold prospect. Sampling along several old (1970s) trenches at the Gezzi prospect show potential for porphyry style, disseminated copper-gold mineralization within a gabbro intrusion. The trenches cover an area approximately 750 feet by 450 feet. The best 6.6-foot chip sample collected along the trenches contained 1.42 percent copper and 0.020 ounces per ton gold.

Nevada Star also staked 36 new claims (720 acres) to cover a mineralized portion of the Rainy Complex. Nevada Star's claims now cover the entire Rainy mafic-ultramafic complex, one of the largest (12 miles long by up to 1 mile wide) in the MAN project area. The newly acquired claims cover a zone of disseminated to net-textured sulfide mineralization, traced in float along a 2,400 -foot length. Two grab float samples collected during the past field season had geochemical results of up to 1.15 percent nickel, 1.27 percent copper, 0.02 ounces per ton platinum, 0.035 ounces per ton palladium, and 0.019 ounces per ton gold.

The MAN project area was also the focus of ground and airborne geophysical surveys by the USGS and BLM, as well as regional metallogenic studies by Dr. Larry Hulbert of the Geological Survey of Canada. Results of these studies, when published over the next several months, are expected to add significantly to the understanding of the mineral potential of the Nikolai intrusive-extrusive complex. These studies will aid in target definition, particularly in the southern Tangle area, believed to host significant potential for nickel-PGE discovery in an area that is obscured from direct observation by a thin cover of glacial overburden.

Golconda Resources Ltd., as operator and 51 percent owner, with joint venture partners Shear Minerals Ltd. and Shulin Lake Mining Inc., announced what is thought to be the first ever lode diamond discovery in Alaska at their Shulin Lake property in southcentral Alaska near Talkeetna. In the spring of 2002, Golconda drilled 11 holes (totaling more than 4,900 feet), of which the last six holes were core holes into what is interpreted, based on petrographic work, to be a maar-like sequence of interbedded volcaniclastic and tuffaceous rocks containing olivine and pyroxene. The holes were spaced over an area of about 2,000 feet by 1,000 feet and intersected an interfingering sequence of clay-altered tuffs and reworked pyroclastics. The reworked pyroclastics contain fragments of volcanic breccias, pebbles, mafic to ultramafic fragments, and are thought to represent the crater facies of a volcanic pipe like structure. The material is interpreted to be locally derived, as most of the fragments are still partly coated with fine-grained tuffaceous material. Golconda interprets the geometry of this unit to show similarities to lamproitic intrusions. Golconda personnel collected a total of 18 random samples from drill holes 8 through 10. Samples were shipped to Lakefield Research Ltd. for caustic fusion and diamond recovery. A 22-pound sample contained 15 microdiamonds (defined as less than 0.02 inches in one direction with a minimum dimension of 0.004 inches in one direction) and one macrodiamond measuring 0.028 by 0.022 by 
0.018 inches. Lakefield characterizes these diamonds as generally being white, transparent, mostly fragments, some with crystal faces, frosted surfaces, and graphite coatings. This sample was taken from hole 10 at a depth from 574 to 609 feet. All 18 samples yielded synthetic diamonds derived from the drilling operation including 44 synthetic diamonds from the diamondiferous sample described above.

Five additional samples from the spring drilling were sent to Lakefield Research for micro-diamond analysis. These samples were taken from drill hole 10 in order to follow up the diamond discovery. One microdiamond was recovered from a sample taken from 562 to 574 feet directly above the diamond-bearing zone. This diamond-bearing interval is described as being a graded sequence of volcaniclastic rock with a thickness of 47 feet.

The Shulin Lake joint venture later completed a second drill program that followed up the diamond-bearing zone. A total of five holes were drilled (02-11 to 02-15) totaling 3,221 feet. The graded horizon similar to that from hole 10 was recognized in several of the new drill holes from which samples will be sent for microdiamond analysis and indicator mineral chemistry. No results were announced from the later drilling.

A review by Golconda of airborne geophysical data from the Shulin Lake property recognized anomalies and structural trends north of the current drilling area that are coincident with features from satellite imagery. One anomaly is a complex circular feature 1.2 miles in diameter interpreted to be a volcanic center (potential pipe) and the source of the diamondiferous volcanic system. No outcrops are present in the area, but two samples spaced about one-quarter mile apart were taken from the bottom of little rivulets. One sample contained mostly granitic components and the other contained mainly volcanic components, but both samples contained fresh single grains of chrome diopside. The joint venture staked additional claims covering 4,500 acres and now controls an area of about 18,000 acres. In February 2003, when the ground is frozen, a bulldozer will dig exploration trenches and drilling will begin shortly thereafter. The geologic context of this diamond discovery continues to be discussed within the Alaskan exploration community.

\section{Southwestern Region}

News from the Donlin Creek gold project dominated Alaska's exploration sector during 2002. A new resource announced in early 2002 increased measured and indicated resources to 4.4 million ounces of gold grading 0.152 ounces per ton, and inferred resources to 6.2 million ounces of gold grading 0.152 ounces per ton. Total resources are 22.9 million ounces of gold at an average grade of 0.09 ounces per ton, ranking Donlin Creek as the 22nd largest gold deposit ever discovered in the world.
Continued aggressive exploration during 2002 added to these resources, with new discoveries at Akivik Zone, Aurora Zone, and Far East Zone. During the 2002 program, NovaGold completed 347 drill holes (195 core holes and 152 rotary holes) for a total of 167,352 feet. This includes 128,472 feet of core drilling and 38,880 feet of rotary drilling in 2002.

Highlights from the 2002 core drilling program at Donlin Creek are numerous. In the ACMA area, mineralized intercepts include hole DC02-679 with 297.3 feet grading 0.13 ounces per ton gold, drill hole DC02-870 with 183.7 feet grading 0.21 ounces per ton gold, drill hole DC02-878 with 53.3 feet grading 0.39 ounces per ton gold. In the Akivik area, gold mineralization is largely within Kuskokwim Group sedimentary rocks and results from drilling include: hole DC02-673 with 58 feet grading 0.26 ounces per ton gold, hole DC02-677 with 195 feet grading 0.20 ounces per ton gold and 150 feet grading 0.18 ounces per ton gold, hole DC02-688 with 59 feet grading 0.16 ounces per ton gold, hole DC02-723 with 52.5 feet grading 0.96 ounces per ton gold; and hole DC02727 with 57.4 feet grading 0.20 ounces per ton gold, hole DC02-856 with 22.6 feet grading 0.607 ounces per ton gold, hole DC02-858 with 12.8 feet grading 0.367 ounces per ton gold and another intercept of 25.25 feet of 0.114 ounces per ton gold, hole DC02-887 with 63.1 feet grading 0.26 ounces per ton gold, and hole DC02-941 with 82.0 feet grading 0.21 ounces per ton gold and another 59.9 foot interval grading 0.27 ounces per ton gold. Follow-up core holes at the new Aurora and 400 gold zones intercepted high-grade gold mineralization including: hole DC02-730 with 20 feet grading 0.16 ounces per ton gold, hole DC02-732 with 26 feet grading 0.13 ounces per ton gold and 23 feet grading 0.11 ounces per ton gold, and hole DC02-744 containing 223 feet grading 0.10 ounces per ton gold (including 103 feet grading 0.15 ounces per ton gold), hole DC02-740 with 45.9 feet grading 0.27 ounces per ton gold, hole DC02-741 with 65.6 feet grading 0.23 ounces per ton gold, and hole DC02-855 with 62.3 feet grading 0.19 ounces per ton gold, 42.7 feet grading 0.21 ounces per ton gold and 107 feet grading 0.13 ounces per ton gold. At the Far East zone, reversecirculation drilling included drill hole DR02-786, which intersected four significant intervals of mineralization, the best of which was 40 feet grading 0.23 ounces per ton gold.

A new interim resource estimate for the Donlin Creek gold deposit announced late in 2002 indicated nearly a 40 percent increase in inferred gold resources by 4.0 million ounces at a discovery cost of less than $\$ 2$ per ounce. This estimate is based on core drill results through October 2002 primarily in the new Akivik, Aurora, and 400 target areas. These new resource areas are outside the main Acma and Lewis deposit areas. Assay results 
from the late-year South Acma, South Aurora/400 drilling were not available in time for inclusion in this estimation. Due to the widely spaced ( 325 feet by 325 feet) core drilling in these areas these new resources are all in the Inferred category. The previous Inferred Resource as defined in the March 2002 Scoping Study using a 0.058 ounces per ton gold cut-off grade was estimated at 10.9 million ounces grading 0.107 ounces per ton gold. The new total Inferred Resource has increased to 14.8 million ounces grading 0.102 ounces per ton gold with a total Measured and Indicated Resource of 8.3 million ounces grading 0.102 ounces per ton gold using a 0.058 ounces per ton gold cut-off grade.

NovaGold completed its required $\$ 10$ million expenditure requirement to earn a 70 percent interest in the Donlin Creek Project from Placer Dome. NovaGold's accelerated exploration program more than doubled the higher grade contained gold estimates at the Donlin Creek gold project and a preliminary independent economic assessment study completed last spring confirmed that the project may be developed into a major new gold producer that, with additional exploration and engineering work, could produce 1 million ounces of gold per year.

Placer Dome has until mid-February 2003 to determine its future level of participation in the Donlin Creek Project and is considering whether to contribute to the development of the Donlin project at a 30 percent participating interest level with NovaGold remaining as operator at 70 percent ownership; or choose to earn an additional 40 percent interest in the project in 5 years or less, by spending a minimum of $\$ 30$ million toward project development, completing a project feasibility study, and committing to build a mine that produces not less than 600,000 ounces of gold per year. Under the latter option Placer Dome would not earn any incremental additional interest in the project above their current 30 percent level until all of the above conditions are met within the maximum 5-year timeframe. NovaGold would not be required to contribute any additional funding up to $\$ 30$ million and at NovaGold's election Placer Dome would assist with financing for any development costs exceeding $\$ 30$ million, with NovaGold's share of the development costs to be repaid out of a portion of its future mine cash flow.

Northern Dynasty Minerals made three important new discoveries during an exploration drilling program at the Pebble project located near Lake Iliamna. The program consisted of 68 widely spaced core holes $(37,000$ feet total) within the 34.3-square-mile copper-gold-molybdenum mineralized system that extends 13 miles southwest of the known 1-billion-ton Pebble deposit that contains 6.6 billion pounds of copper and 10.9 million ounces of gold.

A new copper-gold-molybdenum porphyry deposit was discovered by drill holes 34 and 38, spaced 1,475 feet apart and located 7.5 miles southwest of the Pebble de- posit. Both holes encountered wide intervals of gold-copper-molybdenum porphyry-style mineralization. Hole 34 intersected 210 feet of mineralization, starting at 70 -foot depth, grading 0.30 percent copper and 0.006 ounces per ton gold. Hole 38 intersected 525 feet of mineralization starting at 116 -foot depth grading 0.32 per cent copper, 0.02 percent molybdenum, and 0.010 ounces per ton gold. Assay results show excellent continuity of mineralization and correlation between gold and copper values. The new porphyry copper-gold-molybdenum discovery is wide open in all directions and occurs in a 3.9-square-mile covered area associated with a very extensive induced polarization (IP) chargeability anomaly. The closest drill hole to the discovery is 1.2 miles to the east.

Substantial copper-gold values in chalcopyrite-pyrrhotite skarn-style mineralization were encountered in drill hole 37, located 10 miles to the southwest of the Pebble deposit and 3.1 miles west of hole 38 . Drill hole 37 intersected 259 feet grading 0.4 percent copper and 0.029 ounces per ton gold, which included 21.3 feet grading 30.106 ounces per ton gold and 1.72 percent copper starting at 155.5 -foot depth. This newly discovered copper-gold body is associated with a very strong, 0.6-mile-long, east-west-trending gold-copper soil geochemical anomaly that is open-ended in both directions.

High-grade gold was encountered 3.1 miles south of the Pebble deposit. Drill hole 25 intersected 0.84 ounces per ton gold over 20 feet starting at a 230 -foot depth. This hole is situated within an intense gold-in-soil geochemical anomaly, measuring one-half mile by one-half mile, and is 1,150 feet southwest of historic Teck Cominco drill hole 9 , which intersected an interval grading 0.99 ounces per ton gold over 5 feet. The discovery is open in all directions.

Ventures Resource Corp. announced results from a 2002 field program at its Donlin Creek North claim blocks, and at Golden Apex in the 85,000-acre Flat (Iditarod mining district) property. The $\$ 480,000$ program was managed by WGM Inc. Ventures expanded its 17,000-acre Donlin Creek North project Timb claim block by staking an additional 4,800 acres (7.5 square miles). The Donlin Creek North group includes the Timb, Widg, Mose, and Eldo claim blocks that are strategically located between two gold districts. On the south, the Timb claims abut NovaGold's Donlin Creek deposit. On the north, Donlin Creek North claims cross the southeast part of the 85,000-acre Flat Property in the Iditarod mining district. About 1,800 stream sediment samples were taken in an 800 -square-mile area encompassing 15 Donlin Creek North claim blocks. Samples of quartz stockwork veined rhyolite and associated hornfels, collected during 2002 in the Timb extension area, contain up to 0.0016 ounces per ton gold and anomalous gold pathfinder elements, including silver (up to 1.3 ounces per ton), arsenic (up to greater than 1 percent), 
mercury (up to 0.003 percent) and antimony (up to 0.1 percent), and up to 4.9 percent copper and 12.6 percent lead. Quartz veined rhyolite on the SD property contained up to 0.01 ounces per ton gold and 0.12 percent arsenic.

At the Ada claims, 20 miles east of Flat, Ventures discovered an epithermal gold occurrence. Rocks are cut by faults associated with breccia that contains silicified igneous and wallrock fragments, with sulfides in chalcedonic silica flooding. Twenty-six rock samples contain up to 0.037 percent mercury, up to 0.385 percent antimony; and five samples contain detectable gold values ranging from 0.0013 to 0.022 ounces per ton gold. Soil sampling outlines an 800 - by 1,800 -foot area with more than 0.0006 ounces per ton gold, open in all directions. Very high mercury and antimony values, anomalous gold, and the alteration, brecciation, and chalcedonic silicification indicate possible epithermal gold systems.

In 2003, Ventures anticipates startup of drilling at the Golden Apex and Divide properties, detailed examination of the Ada claims, upgrading of other Flat prospects to the drilling phase, and follow-up of additional Donlin Creek North prospects. In an effort to accelerate its various mineral programs, Ventures is exploring joint venture and other financing options.

Exploration for placer gold and platinum was conducted on Boob Creek in the Tolstoi mining district with test placer cuts through 20 to 35 feet of overburden. Most work on the Tolstoi property and Boob Creek was to test the placer potential of gravels beneath approximately 20 to 35 feet of overburden. Placer gold recovered from a test pit measuring 30 feet by 150 feet by 150 feet exhibited highly variable forms from wires to well-rounded grains. The PGE:Au ratio is approximately 1:100 for placer mineralization. Pyrite recovered in the placer concentrates occurs as rounded balls to crystal fragments and as disseminated grains and veins in the underlying, partially silicified mudstone bedrock. A sample of pyrite from placer concentrates assayed 0.90 ounces per ton gold, 0.10 percent arsenic, 0.06 percent copper, and trace amounts of mercury.

\section{Southeastern Region}

Quaterra Resources Inc. announced that a helicopterborne geophysical survey on its 100-percent-owned Duke Island copper-nickel-PGE prospect identified an extensive zone of potential sulfide mineralization system in an unmapped and unsampled area of the 10- by 12-mile island. The Aeroquest Ltd. helicopter-borne IMPULSE multifrequency electromagnetic and magnetometer survey used an electromagnetic system with a 6-channel frequency domain towed bird system. The survey was completed at a 656-foot line spacing (448 line miles) with105 line miles of fill-in lines at 328-foot spacing in selected areas. The nominal EM bird terrain clearance was 100 feet. Results from the 554-line-mile survey are that areas of known mineralization generally fall within broad zones of anomalous conductivity that extend well beyond the limits of outcropping sulfides. Aeroquest identified a total of 459 high-priority anomalies, including 311 Type 1 anomalies with positive inphase response and a sharp, probable hardrock source and 148 Type 2 anomalies with a negative inphase and positive quadrature response (conductive magnetic anomalies). The largest zone of conductive anomalies occurs on the north side of the Discovery Zone and extends for 1.5 miles in an east-west direction. This zone is well north of the area drilled by Quaterra last year.

Quaterra also reported that a detailed review of the airborne geophysical survey has confirmed a number of high-priority targets. The review, by consulting geophysicist Joseph R. Inman, covered a 2.5 -mile by 2.5 -mile area and identified nine discrete, multi-anomaly zones with strike lengths ranging from 1,300 to 4,900 feet that may be indicative of massive-sulfide mineralization. Quaterra said its 2002 program at Duke Island focused on prioritizing targets for the next drilling campaign, now projected for spring 2003. Quaterra has been following up on surface sampling that returned values ranging from anomalous up to 2.8 percent copper, 0.25 percent nickel and 0.0292 ounces per ton combined platinum and palladium, and on four late 2001 drill holes from two drill pads approximately 750 feet apart. All holes intercepted disseminated, semimassive and massive sulfides over extensive lengths.

Quaterra also reported that the joint venture to explore the Union Bay PGE prospect north of Ketchikan has been terminated to permit Quaterra to focus its resources on its 100 -percent-owned projects. After that option was terminated, Freegold Ventures Ltd. (Freegold) and Pacific North West Capital Corp. (PFN) entered into an option/jointventure agreement on the Union Bay Platinum Project. PFN may earn a 50 percent interest in the project by completing exploration expenditures totaling $\$ 1$ million, participating in the current Freegold financing for $\$ 165,000$, making cash payments totaling $\$ 100,000$ over 4 years, and issuing 60,000 PFN shares. PFN may earn a 60 percent interest by completing a feasibility study, and a 70 percent interest by arranging all financing through to commercial production. The Union Bay Property is centered on a 7.5-mile by 4.3-mile zoned Ural-Alaska complex consisting of a dunite core grading outward through olivine pyroxenite and pyroxenite to hornblendite and gabbro. Freegold originally acquired the property in 2000 after a regional review of PGE potential in the Alexander Platinum Belt of southeastern Alaska. Initial efforts were concentrated on the northeastern part of the Union Bay complex where government surveys indicated values up to 0.55 ounces per ton platinum in pan concentrates.

Results from unpublished graduate thesis work conducted at the University of Alaska Fairbanks on PGE 
mineralization at the Union Bay prospect have major implications for exploration. Most significant are results from multidisciplinary studies that indicate that PGE mineralization is due to hydrothermal fluids and not a primary magmatic genesis. Pyroxene veins crosscut all other rock units and PGE-bearing magnetite is associated with the pyroxene. Magnetite veins clearly cut magmatic layering.

Kennecott Minerals Co. continued exploration to expand ore zones at the Greens Creek Mine. Exploration remained focused on the silver-rich 200 South orebody, where new resources were successfully identified in 2001 and 2002.

Olympic Resources Group LLC discovered new volcanogenic massive-sulfide mineralization with a hydrothermal precious-metal overprint on the southern part of Woewodski Island. Mineralization is hosted in highly quartz-sericite-altered mafic volcanic tuff and tuff breccia of the late Triassic Hyd Group. Mineralization can be traced laterally for 6,000 feet and consists of massive to semimassive pyrite, sphalerite, and galena and as yet unidentified silver- and gold-bearing minerals. A small quartz monzodiorite intrusion, coincident with a strong magnetic low in a regional airborne geophysical survey, occurs in the center of the prospect area and induced an apparent hydrothermal overprint and introduced a secondary gold mineralizing event. Olympic Resources completed a five hole (1,100 feet) diamond drilling program in the Brushy Creek area. Holes 4 and 5 contained mineralized intercepts, with the best intercept from hole 4 from 115 to 196 feet containing 1.65 percent zinc, 0.35 percent lead, 0.97 ounces per ton silver, and 0.007 ounces per ton gold, including 7 feet (from 175 to 182 feet) of 4.66 percent zinc, 0.82 percent lead, 1.88 ounces per ton silver, and 0.017 ounces per ton gold. A total of 160 drill samples were collected for geochemical analysis.

\section{DEVELOPMENT}

Reported expenditures for mine development projects in Alaska in 2002 were $\$ 33.5$ million, compared with $\$ 81.2$ million in 2001.

Development in 2002 was reported at Fort Knox, True North, Usibelli, Kensington, and Greens Creek mines and the Pogo project. There was also a minor amount of development reported at many of the small rock quarries, gravel pits, and placer gold mines. For the first time in many years, there was no development at Red Dog Mine.

At Nolan placer gold mine near Wiseman in northern Alaska, Silverado Gold Mines Ltd. began tunneling into the deep channel on claims 1 and 2 below Discovery between Faye and Archibald creeks.

At Fort Knox Mine development consisted of in-pit drilling, engineering, design, and construction of a tailings thickening system, and raising the level of the tailings dam. At True North Mine, Fairbanks Gold Mining Inc. purchased a new fleet of haul trucks, and began expansion of the mine area after receiving final permit approval in June and overcoming objections in August.

At the Pogo gold project east of Fairbanks, Teck-Pogo, Inc. and partner Sumitomo Metal Mining America Inc. conducted a core-drilling program of infill drilling of the L2 vein to update the indicated/inferred resource calculations, and to assist in geotechnical modeling. The field activity was concurrent with preparation of a Draft Environmental Impact Statement and engineering studies.

In southeastern Alaska Coeur Alaska continued its efforts to permit the Kensington/Jualin Mine complex north of Juneau. Optimization studies of new mining methods reduced the cost of the mine by more than $\$ 56$ million, and the operating costs from $\$ 282$ per ounce to $\$ 226$ per ounce.

At Greens Creek Mine Kennecott Minerals/Hecla completed construction of their paste backfill plant, enabling the mill throughput to be increased to record level, and continued drifting to access the orebody.

At Usibelli Coal Mine near Healy construction of a 7mile-long road and stripping of the Two Bull Ridge pit prepared for the move of the walking dragline from the operating Poker Flats pit.

\section{PRODUCTION}

The estimated value of mine production in 2002 is $\$ 968.2$ million, an increase of 5.5 percent over the $\$ 917.3$ million reported in 2001. Of this total, $\$ 822.3$ was for metals, $\$ 108.3$ million was for industrial minerals, and $\$ 37.6$ million was for coal and peat. These values are preliminary and may change as more information becomes available. Table 4 shows the estimated mineral production for 2000 through 2002.

Significant Alaskan production sites for minerals during 2002 are shown in figure 2. Gold production was reported from Fort Knox, Greens Creek, and Illinois Creek hard rock mines, and at least 40 placer mines. Silver was produced at Red Dog and Greens Creek mines, which were also the primary producers of zinc and lead concentrates.

At Red Dog Mine near Kotzebue in northwestern Alaska 3,489,600 tons of ore were milled, down 71,000 tons from the year before. However, the Mill Optimization Project of past years resulted in production of a record $1,366,480$ tons of concentrate with 637,800 tons of contained zinc and 118,880 tons of contained lead, and an estimated 6.75 million ounces of silver. The ore grade was 21.1 percent zinc, 5.4 percent lead, and 2.7 ounces per ton silver. Despite the higher grade of ore and better recovery, the average price of zinc in $2002(\$ 0.35)$ was so much lower than the 2002 average $(\$ 0.40)$ that the mine reported a loss of \$28 million for the year. In July 2002 Red Dog 
Table 4. Estimated mineral production in Alaska, 2000-2002 ${ }^{a}$

\begin{tabular}{|c|c|c|c|c|c|c|}
\hline \multirow[b]{2}{*}{ Metals } & \multicolumn{3}{|c|}{ Quantity } & \multicolumn{3}{|c|}{ Estimated values $^{b}$} \\
\hline & 2000 & 2001 & 2002 & 2000 & 2001 & 2002 \\
\hline Gold (ounces) & 551,982 & 550,644 & $559,713^{c}$ & $\$ 154,058,000$ & $\$ 149,246,000$ & $\$ 173,545,000$ \\
\hline Silver (ounces) & $18,226,615$ & $16,798,000$ & $17,858,183$ & $90,404,000$ & $73,408,000$ & $82,326,000$ \\
\hline Copper (tons) & 1,400 & 1,400 & 1,600 & $2,296,000$ & $1,988,000$ & $2,272,000$ \\
\hline Lead (tons) & 123,224 & 127,385 & 146,462 & $51,754,000$ & $56,049,000$ & $61,514,000$ \\
\hline Zinc (tons) & 669,112 & 634,883 & 718,106 & $682,494,000$ & $507,907,000$ & $502,674,000$ \\
\hline Subtotal & & & & $\$ 981,006,000$ & $\$ 788,598,000$ & $\$ 822,331,000$ \\
\hline \multicolumn{7}{|l|}{ Industrial minerals } \\
\hline Jade and soapstone (tons) & 2.0 & 2.0 & 2.0 & 25,000 & 25,000 & 25,000 \\
\hline Sand and gravel (million tons & 10.6 & 10.4 & 18.0 & $49,855,000$ & $55,221,000$ & $95,940,000$ \\
\hline Rock (million tons) & 5.2 & 3.1 & 1.4 & $36,588,000$ & $27,176,000$ & $12,306,000$ \\
\hline Subtotal & & & & $\$ 86,468,000$ & $\$ 82,422,000$ & $\$ 108,271,000$ \\
\hline \multicolumn{7}{|l|}{ Energy minerals } \\
\hline Coal (tons) & $1,473,000$ & $1,537,000$ & $1,158,000$ & $\$ 38,768,000$ & $\$ 48,108,000$ & $\$ 37,400,000$ \\
\hline Peat (cubic yards) & 35,600 & 36,000 & 35,000 & 178,000 & 180,000 & 175,000 \\
\hline Subtotal & & & & $\$ 38,946,000$ & $\$ 48,288,000$ & $\$ 37,575,000$ \\
\hline TOTAL & & & & $\$ 1,106,420,000$ & $\$ 919,308,000$ & $\$ 968,177,000$ \\
\hline
\end{tabular}

Figure 2. Selected significant production sites in Alaska, 2002. 
employed 521 regular employees and 59 temporary or casual employees, for a total of 580 . Of these, 59 percent were shareholders of the NANA Regional Corp.

Fairbanks Gold Mining Inc. (FGMI), a subsidiary of Kinross Gold Corp., is the operator of Fort Knox Mine and the satellite True North Mine about 25 miles north of Fairbanks. During 2002, with a workforce of 360, FGMI recovered 410,519 ounces of gold from 15.26 million tons of ore milled. The ore was derived from 11.5 million tons mined at True North, and 24.5 million tons mined at Fort Knox.

American Reclamation Group LLC. continued leaching gold from 385,000 tons of ore added to the existing heaps at Illinois Creek Mine, and conducted a limited exploration program designed to prospect for the northward extension of the vein in the East Pit. The mine employs 53 workers, many of whom are from the nearby villages of Ruby, Galena, Huslia, Kaltag, and Nulato.

With a workforce of 262 people Kennecott Minerals milled a record 733,507 tons of ore in 2002, up 11.5 percent from the 658,000 tons milled in 2001. Head grade of the ore was 12.52 percent zinc, 4.73 percent lead, 19.73 ounces per ton silver, and 0.203 ounces per ton gold. The concentrate contained 80,306 tons of zinc, 27,582 tons of lead, 10, 913,183 ounces of silver, and 102,694 ounces of gold. At the beginning of 2003 the proven/probable reserve stood at 7.05 million tons of 11.4 percent zinc, 4.2 percent lead, 14.9 ounces per ton silver, and 0.13 ounces per ton gold. Other resources were 2.7 million tons at 11.3 percent zinc, 4.9 percent lead, 17.0 ounces per ton silver, and 0.13 ounces per ton gold.

The total amount of coal mined from the Usibelli Coal Mine (UCM) near Healy in 2002 was 1,157,879 tons, considerably less than in past years. The reason for the decline was the expiration of its coal export contract with the Korean electric power company KEPCO. UCM was forced to lay off 30 of its 110 employees during 2002. The mine did continue shipping coal to Korea through September to fulfill existing contract obligations, but the total of 310,646 tons for 2002 was down substantially from prior years. Since the first shipment in 1984, UCM has shipped 12.4 million tons of coal to Korea through the port of Seward, providing revenue and jobs for the Alaska Railroad, and also for the coal-loading facility in Seward.

Production from about 40 placer gold mines was about 20,000 ounces, slightly less than the 22,841 ounces reported in 2001. The decline was the least in over 4 years, and with a significant increase in the price of gold late in the year, placer gold production is expected to increase next year.

Production of sand and gravel in 2002 was a minimum of 18.04 million tons, almost double that of 2001. Most of the use was for scheduled roadwork in southcentral and interior Alaska, but flooding on the Kenai and major earthquake damage in the eastern interior required major road repairs late in the year. As usual, there was a large amount of sand and gravel used in the North Slope oilfields.

Demand for rock declined sharply from past years to only about 1.4 million tons, with most of the decline in southeast Alaska because the U.S. Forest Service was not constructing many roads.

\section{DRILLING}

Drilling was conducted during all phases of mining (exploration, development, and production) on various projects across Alaska during 2002. Preliminary drilling totals for 2002 are 398,557 feet of core drilling and 107,580 feet of reverse-circulation drilling. Hardrock core (sometimes referred to as hardrock diamond drilling) footage in 2002 is approximately 59 percent higher than the 240,318 feet reported drilled in 2001. Reverse-circulation drilling footage also increased, approximately 42 percent higher than the 75,750 feet reported drilled in 2001. Hardrock core footage for 2002 is approximately 11 percent lower than the average core footage reported in Alaska from 1996 to 2001. Reverse-circulation drilling footage for 2002 is equal to the average reverse-circulation drilling footage from 1996 to 2001. Drilling at placer mines was largely unreported for 2002, with 1,250 feet reported

Table 5. Drilling footage by region in Alaska, 2002

\begin{tabular}{|c|c|c|c|c|c|c|c|}
\hline Type of drilling & Northern & Western & $\begin{array}{l}\text { Eastern } \\
\text { interior }\end{array}$ & $\begin{array}{l}\text { South- } \\
\text { central }\end{array}$ & $\begin{array}{c}\text { South- } \\
\text { western }\end{array}$ & $\begin{array}{l}\text { South- } \\
\text { eastern }\end{array}$ & TOTAL \\
\hline Placer subtotal & - & - & 1,250 & -- & - - & - & 1,250 \\
\hline Coal subtotal & -- & -- & -- & -- & -- & -- & -- \\
\hline Hardrock core & 7,136 & 20,630 & 71,712 & 7,579 & 165,472 & 109,828 & 382,357 \\
\hline Hardrock rotary & - - & 1,200 & 65,000 & 2,500 & 38,880 & -- & 107,580 \\
\hline Hardrock subtotal & 7,136 & 21,830 & 136,712 & 10,079 & 204,352 & 109,828 & 489,937 \\
\hline TOTAL (feet) & 7,136 & 21,830 & 137,962 & 10,079 & 204,352 & 109,828 & 491,187 \\
\hline
\end{tabular}

- - = Not reported.

Note: 500,000 feet of blasthole drilling reported (incomplete). Drill footages do not include sand and gravel drilling. 
Table 6. Drilling footage reported in Alaska, 1982-2002

\begin{tabular}{|c|c|c|c|c|c|c|c|c|}
\hline Year & $\begin{array}{c}\text { Placer } \\
\text { Exploration }\end{array}$ & $\begin{array}{c}\text { Placer } \\
\text { Thawing }\end{array}$ & $\begin{array}{c}\text { TOTAL } \\
\text { PLACER }\end{array}$ & $\begin{array}{l}\text { TOTAL } \\
\text { COAL }\end{array}$ & $\begin{array}{c}\text { TOTAL } \\
\text { HARDROCK }\end{array}$ & $\begin{array}{c}\text { Hardrock } \\
\text { Core }^{\mathrm{a}}\end{array}$ & $\begin{array}{c}\text { Hardrock } \\
\text { Rotary }^{\mathrm{a}}\end{array}$ & $\begin{array}{c}\text { TOTAL } \\
\text { FEET }\end{array}$ \\
\hline 1982 & 30,000 & 94,000 & 124,000 & 80,000 & 200,000 & -- & - & 404,000 \\
\hline 1983 & 23,000 & 30,000 & 53,000 & 12,000 & 180,500 & -- & - - & 245,500 \\
\hline 1984 & 31,000 & 98,000 & 129,000 & 25,700 & 176,000 & -- & - - & 330,700 \\
\hline 1985 & 46,000 & 34,000 & 80,000 & 8,700 & 131,700 & -- & - & 220,400 \\
\hline 1986 & 32,400 & 227,000 & 259,400 & 28,800 & 50,200 & -- & - - & 338,400 \\
\hline 1987 & 50,250 & 130,000 & 180,250 & 19,900 & 115,100 & 95,600 & 19,500 & 315,250 \\
\hline 1988 & 152,000 & 300,000 & 452,000 & 26,150 & 353,860 & 223,630 & 130,230 & 832,010 \\
\hline 1989 & 97,250 & 210,000 & 307,250 & 38,670 & 332,230 & 242,440 & 89,790 & 678,150 \\
\hline 1990 & 78,930 & 105,000 & 183,930 & 18,195 & 760,955 & 648,600 & 112,355 & 963,080 \\
\hline 1991 & 51,247 & 130,000 & 181,247 & 16,894 & 316,655 & 205,805 & 110,850 & 514,796 \\
\hline 1992 & 6,740 & 65,000 & 71,740 & 12,875 & 359,834 & 211,812 & 148,022 & 444,449 \\
\hline 1993 & 25,216 & - - & 25,216 & - - & 252,315 & 124,325 & 127,990 & 277,531 \\
\hline 1994 & 21,000 & -- & 21,000 & 8,168 & 438,710 & 347,018 & 91,692 & 467,878 \\
\hline 1995 & 27,570 & -- & 27,570 & -- & 415,485 & 363,690 & 51,795 & 443,055 \\
\hline 1996 & 61,780 & -- & 61,780 & 8,500 & $\mathbf{6 5 8 , 8 5 7}$ & 524,330 & 134,527 & 729,137 \\
\hline 1997 & 38,980 & -- & 38,980 & 13,998 & 704,510 & 523,676 & 180,834 & 757,488 \\
\hline 1998 & 33,250 & -- & 33,250 & 2,300 & 549,618 & 505,408 & 45,670 & 585,168 \\
\hline 1999 & 6,727 & -- & 6,727 & - - & 448,797 & 369,863 & 78,934 & 455,524 \\
\hline 2000 & 15,480 & -- & 15,480 & - & 546,268 & 418,630 & 127,638 & 561,748 \\
\hline 2001 & 1,100 & -- & 1,100 & 36,151 & 316,068 & 240,318 & 75,750 & 353,319 \\
\hline 2002 & 1,250 & -- & 1,250 & -- & 489,937 & 382,357 & 107,580 & 491,187 \\
\hline
\end{tabular}

${ }^{a}$ Core and rotary drilling not differentiated prior to 1987.

- - = Not reported.

Note: 500,000 feet of blasthole drilling reported for 2002 (incomplete).

to date. Coal drilling is unreported, but likely occurred at Usibelli Coal Mine. Tables 5 and 6 summarize the drilling activity in the state during 2002 by region and type of drilling. The southwestern region had the most drilling of all Alaska regions, with 42 percent of the total for 2002. The eastern interior region had 28 percent of the drilling, followed by the southeastern region with 22 percent. Major drill programs were conducted by NovaGold Resources Inc. at the Donlin Creek deposit, by Northern Dynasty Minerals Ltd. at the Pebble property, by Chapleau Resources Ltd. at the Kougarok property, by Kinross Gold Corp. in the Fairbanks mining district including Fort Knox and True North mines, by Teck Pogo Inc. at the Pogo property, and by Kennecott Minerals Co. at Greens Creek Mine.

\section{GOVERNMENT AFFAIRS}

At the end of October the True North Mine received a Sentinels of Safety Award from the federal Mine Safety and Health Administration (MSHA) for 135,554 hours without lost time due to a work injury during the construction and startup of the mine.

Ray Lester received a reclamation award from the Alaska Department of Natural Resources for his reclamation activities on Birch Creek in the Circle mining district between 1995 and 2002. The U.S. Bureau of Land Man- agement also received an award from DNR for innovative thinking at the Elim project on the Seward Peninsula, which considerably reduced costs of reclamation.

Airborne geophysical surveys funded by the Alaska Division of Geological \& Geophysical Surveys (DGGS) were flown in the Council area east of Nome. DGGS also released results of surveys from three areas flown in 2001: in the area southeast of the Pogo deposit, in the Broad Pass area south of Cantwell, and in the Bonnifield district east of Healy.

Geophysical surveys funded by the Bureau of Land Management and managed by DGGS were flown in the Denali Block west of Paxson, and in the Red DevilSleetmute area of southwestern Alaska. Existing company data were incorporated into the Denali Block data.

Also in 2002 a strategic 235,000 acres of the Denali Block area, containing some of the best copper-nickelplatinum-group-elements targets, were Tentatively Approved (TA) for transfer to the State of Alaska.

DGGS conducted approximately 60 days of fieldwork in the Salcha River-Pogo area during 2002. Geologic maps covering approximately 420 square miles in the area will be published in June 2003.

The U.S. Geological Survey (USGS) conducted studies over several years on the Red Dog deposit and regional 
setting. Recent results include a possible regional exploration tool for "Red Dog type" massive-sulfide mineralization in Pennsylvanian Kuna shale. Geochemical indications of mineralization include greater than 2 parts per million germanium, greater than 1.2 parts per million thallium, greater than 45 parts per million arsenic, and greater than or equal to 20 parts per million antimony.

During the last two summers, USGS and Calista Native Corp. geologists collected geochemical samples in southwestern Alaska in conjunction with the National Geochemical Survey, a nationwide program designed to establish baseline chemical data in the geologic environment. These data are useful in mineral exploration and environmental studies. More than 350 randomly chosen sample sites were visited in 2001 and 2002. At each site, stream sediment and heavy-mineral concentrate samples were collected for chemical and mineralogical analyses. At many sites, vegetation samples were also collected to evaluate naturally occurring metal uptake by various plant species. In 2002, U.S. Geological Survey geologists also began collecting water samples to study metal concentrations and their transport in surface and subsurface waters in Donlin Creek and the surrounding area. NovaGold Resources hired an independent contractor to conduct similar hydrologic studies on the property. These studies will continue over the next few years to document the natural background concentrations of various metals in the environment prior to future development of a mine at Donlin Creek. This information will be valuable in determining permitting and environmental monitoring requirements at Donlin Creek.

The 2002 USGS program in the Talkeetna Mountains area included gravity and magnetic geophysical studies. Wrangellia terrane, including host rocks for ultramafic intrusions and possible PGE mineralization, were found to be 2 times larger in area than previously mapped and at least 30 miles wider, according to geophysical study results and models. Geophysical models also show two northeast-trending belts with gravity and magnetic features similar to the ultramafic Fish Lake Complex. Magnetotelluric studies include a transect through the Talkeetnas that reveal a "Honking Big Anomaly" that is too dense to be a graphitic schist and is interpreted to be a westward-plunging massive-sulfide body.

The BLM conducted a 7-week field program in the Delta River mining district of eastern and southcentral Alaska. One hundred eight sites (lode, placer, industrial, and coal) were visited and 355 samples were collected. BLM plans to conduct 2 more years of fieldwork and possibly acquire more airborne geophysical data in this area (possibly southeastern portion of area?). 
Front Cover. Core drilling at the Hook Target on the Gobi-Portal property, Goodpaster River area, eastern Interior region, Alaska. Exploration during 2002 on the Gobi-Portal property was funded by AngloGold (USA) Exploration Inc., in a joint venture with Continental Ridge Resources Inc. Photo by David Szumigala.

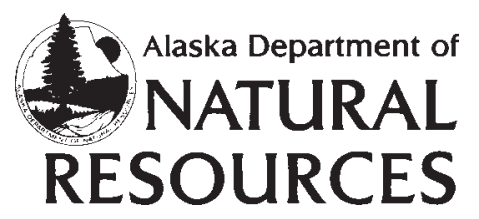

DEPARTMENT OF NATURAL RESOURCES

Division of Geological \& Geophysical Surveys http://wwwdggs.dnr.state.ak.us

\section{DEPARTMENT OF COMMUNITY \& ECONOMIC DEVELOPMENT}

Division of Community \& Business Development

http://www.dced.state.ak.us/trade/ 